\title{
A Culturally Relevant Picture Book for Children's Early Literacy
}

Rita Kurnia, Faculty of Teacher Training and Education, Universitas Riau, Indonesia, Email: rita.kurnia@lecturer.unri.ac.id

This research aimed at designing a picture book which is based on local folktales to support children's early literacy. With observation and one group pre-test post-test experimental design, the main field test was carried out to a total of 120 preschool children aged 5 and 6 years old. Of the total, 43 children were chosen as the control group, while the other 77 children were as the experimental group. An independent sample t-test was used to determine the score difference between the two groups. The findings show that there is an improvement in reading readiness among the experimental group. Therefore, it can be concluded that the use of the local folktale picture book developed in this study can give a positive impact on children's early reading development. The implication of this study is expected to shed light on the importance of local culture in children language development.

Key words: Local culture, folklore, early reading, early literacy, reading readiness

\section{INTRODUCTION}

Learning to read is a long process of development which relies heavily on readiness to acquire such a skill. The success of reading at an early age requires a pertinent instrument which adheres to children's development stage, such as in terms of children's vocabulary (Battle, 2009). Therefore, media availability at school should pay attention to this need. However, it is common in some areas in Indonesia that school is still having a limited number and types of quality learning media.

The importance of reading has gained more attention in Indonesia recently. In 1999, a national survey showed that approximately $10 \%$ of primary school students in Indonesia were not ready to read, write and count (BPS-Statistics Indonesia, 2019). These data lead the Indonesian government to emphasise the importance of literacy for the country's development since 2003. The Indonesian Ministry of Education (MoE) also highlights that the literacy development in early childhood level is vital for the success of the next education level, especially in reading, 
writing and maths. With the formal approach developed in the new curriculum, it enables teachers to prepare children to read. For example, publicly-funded early education institutions are required to hold a weekly literacy program where children are allowed to choose what they want to read. In some schools, teachers can also invite parents to read the chosen books for their children. With the assistance of teachers, the learning activities are developed to allow children to learn gradually from knowing vowels, consonants, syllables, to simple sentences.

However, the success of early literacy is closely related to children's reading interest (Smith \& Chapel, 1970). This might be one of the reasons why most educators would opt for picture books to gain children's interest in learning to read. Pictures and colours presented in a picture book would gain children's attention and lead to better engagement in the reading process. Besides, as the nature of picture book is a story with words, children would have more room to interpret the story based on their perception (Mueller, 2005).

The stories told in the picture books might vary, but the most common ones are either fantasy or folklores. Many have agreed on the importance of fantasy and folklore stories for building children's literacy and build their critical thinking (Lawrence et al., 2017; Roche, 2015; Saccardi, 2014). However, many have also revealed that the fantasy and folklore stories which do not come from children's own culture might make them feeling unfamiliar and less engaged to the reading (Moore, 2017; Perry, 2012; Wood \& Jocius, 2013). This is why there is a need to provide culturally relevant reading materials for children to support their early literacy development.

Culturally relevant reading material has many benefits for children's literacy, future learning and character building. Firstly, reading a text which comes from children's home culture would allow them to engage more with the reading process as they can see themselves in it (GarthMcCullough, 2008; Lohfink, 2010; Parlakian \& Sanchez, 2006; Wood \& Jocius, 2013). This would enable them to understand and value their own culture. By learning their home culture and seeing it in the storybook, children would be able to foster a positive attitude towards their culture and build the feeling of connectedness with their environment (Brooks, 2006; Hefflin \& Barksdale-Ladd, 2001; Norton \& Norton, 2010). It would also be easier for them to absorb good values and virtues of the culture which would lead to positive character building (Hall, 2008). Not only does it help children, but it also helps the culture itself in a way that this culturally relevant literature would give a way to an intergenerational cultural transfer. This is a vital measure to preserve a culture in the era of modernisation like today.

However, most schools and parents tend to rely on the stories available in bookstores, which are likely popular stories coming from Western or other popular places. Very few try engaging with the folklores and fables from their local areas. The reasons might vary, such as limited time to transcribe the story into ready-to-use media in the classroom, or just the lack of popularity. Therefore, this study aimed at designing a picture book which is based on Malay folktales to support children's early literacy development. 


\section{THEORETICAL FRAMEWORK}

\section{Socio-culture, Picture Books and Children's Literacy}

In the last decades, the term 'literacy' has a somewhat broad definition of itself. It is no longer limited to reading and writing, but also other skills such as visual and digital literacy (Wallace, 2013). However, the development of the literacy definition does not seem to diminish the importance of reading and writing skills in children's literacy development. This is why most studies in children's literacy seem to focus on these two skills.

In the process of developing reading and writing skills, children might experience some stages which prepare them to be good readers. This, as pointed out by Teale \& Sulzby (1986), shows that children's literacy starts from the early, pre-school age and their listening and speaking skills develop simultaneously with their reading and writing skills. This has been supported by many studies (e.g. Bauer and Guerero, 2016; Dickinson, McCabe, Anastasopoulos, PeisnerFeinber \& Poe, 2003; Kenner, 2004). The development of these four skills is interrelated to each other during the pre-school and kindergarten age (Jalongo, 2007; Storch \& Whitehurst, 2002). During this age, they can construct longer utterances in limited topics and retell stories (Owen Jr., 2012). However, Teale \& Sulzby (1986) also suggest this process might vary among children depending on many factors, such as children's socio-cultural background, teacher mediation, resources and their language development level.

Even though kindergarten children are not fully able to read books, they might have been familiar with print, sounds and their meaning (Hoff, 2005). They might be able to distinguish between sounds which they acquire from observing their surroundings (Hester \& Hodson, 2009). In this period, children are developing their readiness for reading which Owen Jr (2012) terms as the 'pre-reading phase'. Thus, exposing them to books, songs and conversations would strengthen their development (Mueller, 2005). It is important to select books and other reading materials which meet children's interest, socio-cultural background and development level (Wiseman, 2011). With sufficient support and resources, children might be able to improve their reading readiness (Kenner, 2004) which will support them for their next education level (Kirk \& Gillon, 2007; Manolitsis \& Kandylidou, 2011).

Even though literacy and socio-cultural practices seem to be different sets of skills, they are actually interrelated. In fact, many have agreed that socio-cultural practices which children engage in can significantly influence their process of learning to read and write (Battle, 2009; Lyle \& Bolt, 2017; Perry, 2012; Rogoff, 2003). One of the underexplored cultural practices is a folktale, folklore which uses an animal as the main character of the story. Folktales, which generally come from oral tradition, always contain moral values which are taught through the actions of the animals in the stories (Saccardi, 2014). 
Recently, more and more reading materials are adapted from non-local resources. Some of them even use English as language instruction in early childhood education (Moore, 2017). However, Moore (2017) has documented several studies which focused on the use of English instruction in a non-Western context. These mostly agree, if not all, that the implementation of materials or instructions which do not come from a local culture has contributed negatively to the village students' attainment. Concerning this issue, Battle (2009) even emphasises in her research that children must be given reading materials which are related to their local culture so that they can be more confident during the learning process. This way, it would enable the teacher to improve children' reading readiness as they are already familiar with the content.

As children in their early age are learning to read, they might first observe forms, pictures or objects around them to build a concept of meaning. This is why picture books can serve as effective tools for it. Roche (2015) in her research introduced picture books to preschool children and she found that the picturebooks could increase the children's level of engagement, understanding, critical thinking and oral skills. Even though literacy is taught differently around the world, all seem to emphasise the importance of comprehension and interpretation (Paran \& Wallace, 2016). Therefore, children are generally exposed with printed text as it is believed to convey meaning and encourage them to explore meaning through it (Rhyner, Haebig \& West, 2009). A study conducted by Justice, Kaderavek, Fan, Sofka \& Hunt (2009) also found that storybook reading in the classroom can positively affect children's knowledge in simple writing and their conception towards print. Even though the way storybook reading is carried out might vary in different countries, it consistently shows the similar importance of storybook reading in children's early literacy development (Bay \& Cetin, 2014; Cetin \& Bay, 2015; Tarim, 2015).

In Indonesia, although teaching reading advocated by the MoE promotes the sequenced approach from knowing vowel to simple sentences, it also acknowledges the importance of simultaneous skills development (listening, reading, writing and speaking). That is why early childhood education institutions are encouraged to hold an additional literacy program besides formal learning. In publicly funded schools, for example, parents are invited to school weekly to read a story for their children. The literature would be chosen from what is available at school. However, with the limited number of printed local stories, it is more often than not that the stories chosen are the stories which do not come from children's home culture. This is why there is a need to design a culturally relevant reading materials which can support children's early reading.

\section{METHODOLOGY}

This study was a research and development project with observation and one group pre-test post-test experimental design. It was conducted at three kindergartens in rural Indonesia. The process of this study can be seen in the following figure. 
International Journal of Innovation, Creativity and Change. www.ijicc.net

Volume 14, Issue 11, 2020

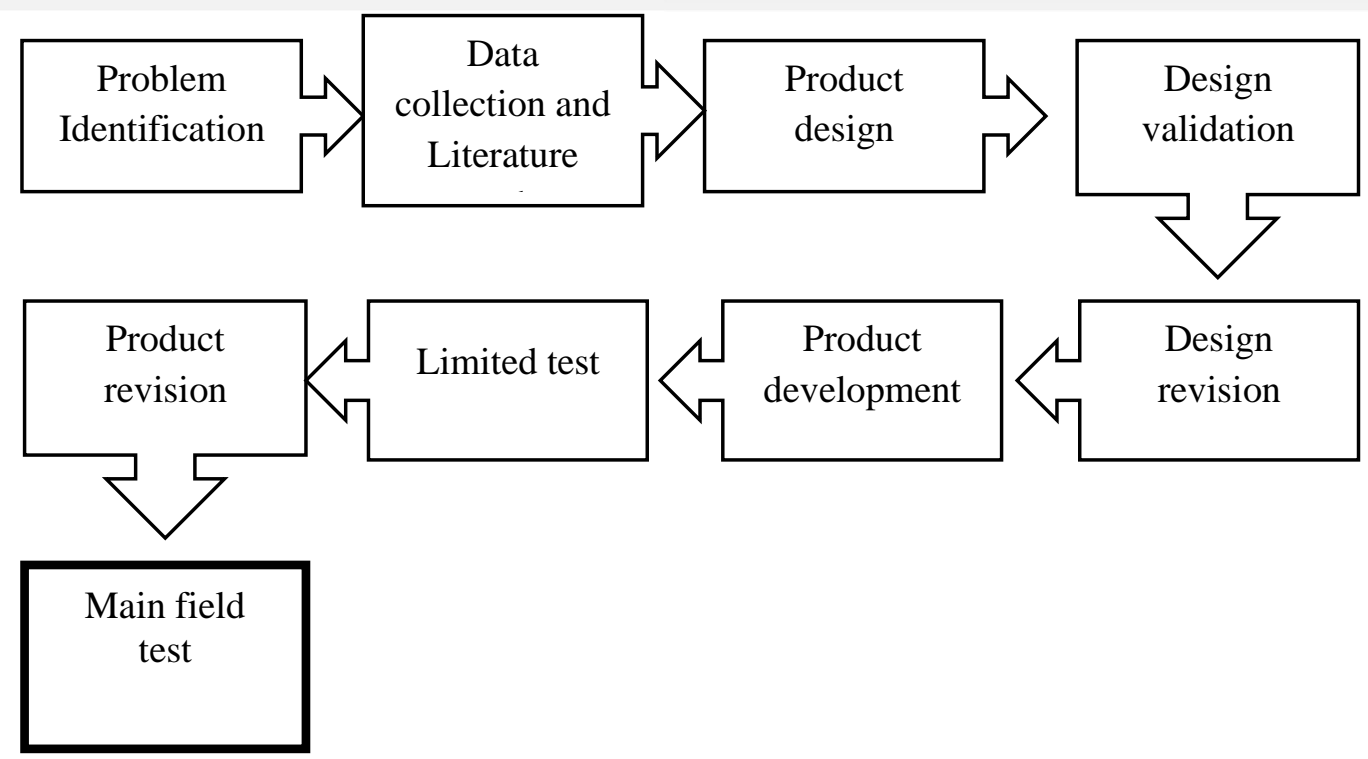

\section{Figure 1. Stages in R\&D}

Before conducting this study, some kindergartens were approached based on the geographic location. Three publicly-funded kindergartens agreed to participate in this study. The data of the participants are as follows:

Table 1. The data of the participants

\begin{tabular}{cccc}
\hline \multirow{2}{*}{ School } & \multicolumn{2}{c}{ Class } & Total \\
\cline { 2 - 3 } & A & B & \\
\hline I & 22 & 21 & 43 \\
II & 23 & 22 & 45 \\
III & 32 & - & 32 \\
\hline & $\mathbf{7 7}$ & $\mathbf{4 3}$ & $\mathbf{1 2 0}$ \\
\hline
\end{tabular}

As a total of 120 children from three kindergartens were considered small in number, so all of them were selected as the participants of this study. They were children aged between 5 and 6 years old. Of the total, 43 children were chosen as the control group, while the other 77 children were as the experimental group. This number was decided based on the school classes, where those with two classes were directly divided into control and experimental group. Since the third kindergarten only had one class, it was then assigned to experimental group. The three schools were public schools with similar curriculum and literacy program, so the students could be considered homogenous. 
Before the study, local folklore about a smart animal named Kancil (a mouse deer) was chosen as the story. To use the story, it was re-written and made into a picture book. In the early stage of the process, the picture book was drawn manually using a pencil. After undergoing a process of validation and revision, the product was pilot tested. The result of the pilot tested was used to revise and design the final product before being given out to the sample of the study.

This process took six months for re-writing, drawing, editing and printing before it was ready to be used as the instrument. The picture book comprised of 18 pages. As the story related to this mythical animal had many versions, the one telling about the mouse deer, the tiger and the elephant was chosen because it tells a message about friendship. Besides, the representation of tiger and elephant was also aimed to familiarise children with these endangered animals.

When conducting the research, the students were tested on their reading readiness using a reading test adapted from Jiar and Othman (2008). The test comprised of 84 items which were divided into 3 sections: Section A contained questions related to students' demographic information, section B was for written test questions and section $\mathrm{C}$ was for spoken test questions. Each correct answer would be scored 1 and incorrect would be 0 . Therefore, the total score of 84 would represent 84 correct answers. The detail of this research instrument can be seen in Table 2.

Table 2. Reading Readiness Test

\begin{tabular}{lll}
\hline Section & Information & No of Item \\
\hline A & Demographic Information & \\
& Written Test: & \\
& 1. Vocabulary Repertoire & 10 items \\
2. Auditory Discrimination & 10 items \\
3. Visual Discrimination & 10 items \\
& Spoken Test (Reading) & 54 items \\
& 1. Random Alphabet & 3 \\
2. CV & 4 \\
3. CV+CV & 4 \\
4. CV+CV+CV & 4 \\
5. V+CV & 4 \\
& 6. V+CVC & 4 \\
& 7. CV+CVC & 4 \\
& 8. CV+CVCC & 4 \\
& 9. CVC+CVC & 4 \\
& 10. Dipthongs & 4 \\
& 11. CV+CV+CVC & 4 \\
12. Reading simple sentences & 6 \\
13. Reading text and comprehension & 5 \\
& &
\end{tabular}

Note: $\mathrm{C}=$ Consonant; $\mathrm{V}=$ Vowel 
International Journal of Innovation, Creativity and Change. www.ijicc.net

Volume 14, Issue 11, 2020

Regarding the classification of the result, it can be divided into three categories namely low, mediocre and high which represent $<55 \%, 55.6-77.7 \%$ and $77.8-100 \%$ correct answers respectively.

\section{FINDINGS}

The storybook designed was assessed by three reviewers in terms of its suitability, readability and language. The product has been approved by the three reviewers coming from the early childhood education department, and Indonesian language and culture department before being pilot tested in a limited number of samples. The followings are examples of the product in every stage of the process.

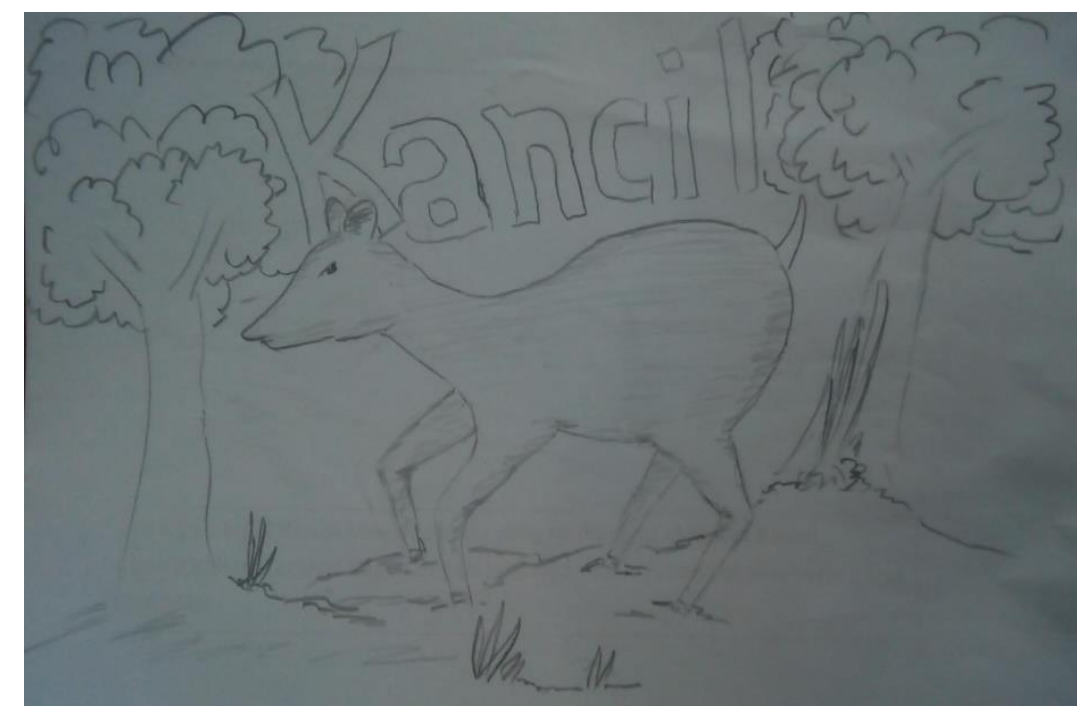

Figure 2. Stage 1 (Media design using pencil)

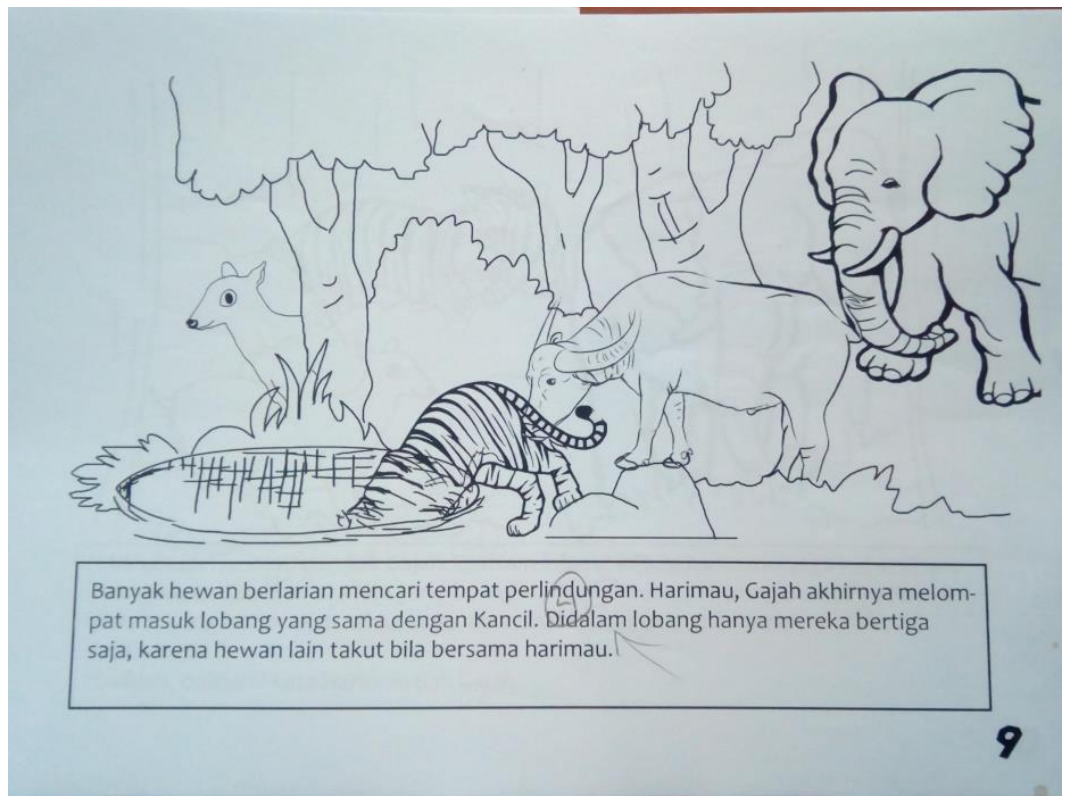

Figure 3. Stage 2 (Media design using computer) 
International Journal of Innovation, Creativity and Change. www.ijicc.net

Volume 14, Issue 11, 2020

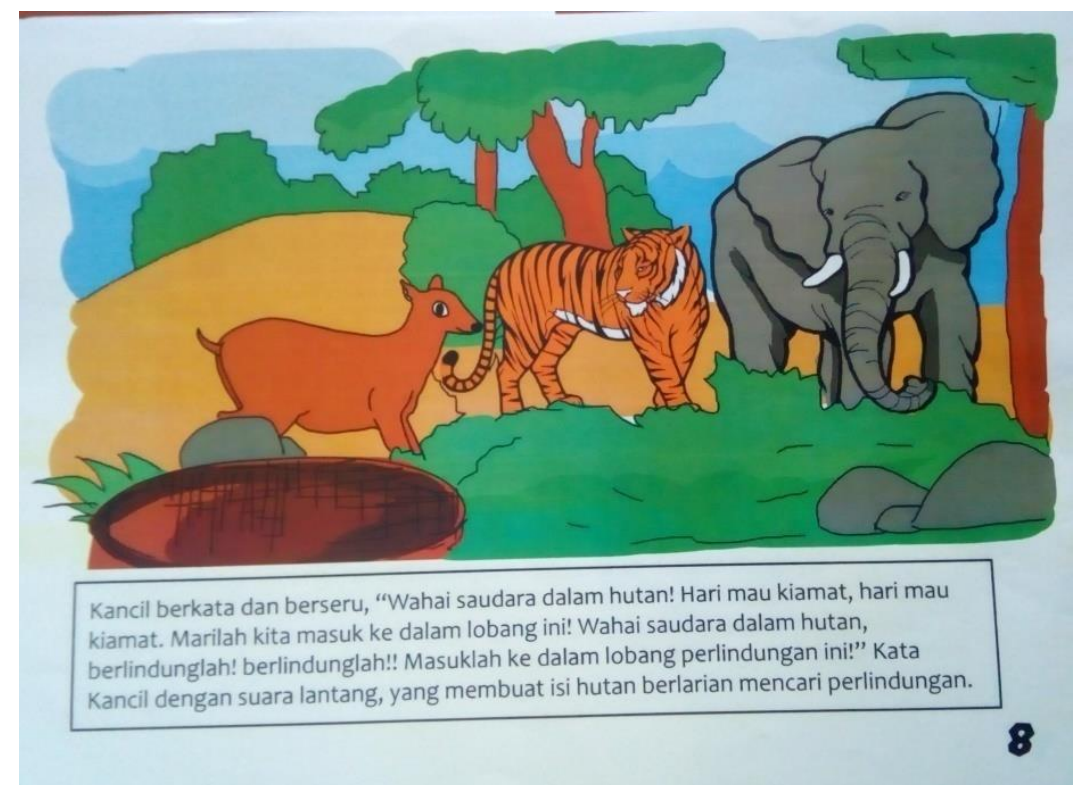

Figure 4. Stage 3 (Media printed on A4 paper)

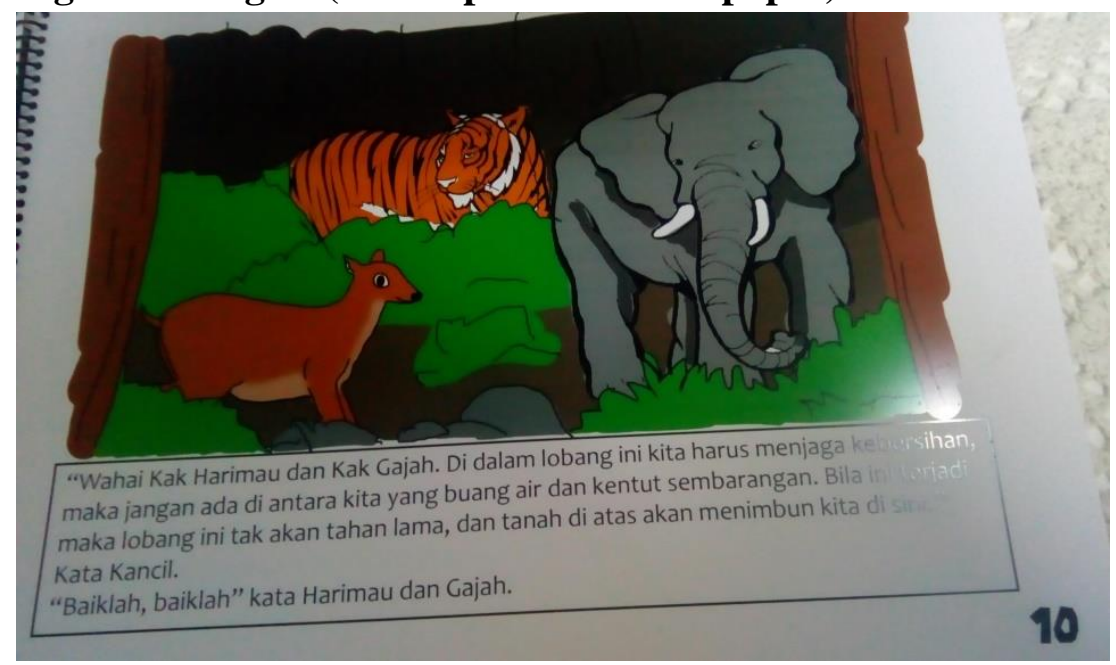

\section{Figure 5. Stage 4 (Final product)}

The final product was then pilot tested to a limited number of samples. This pilot test was carried out in two ways. Firstly, the media was shown to children and they were allowed to touch it and look closely. Secondly, the media was presented by the researcher in front of the classroom. The process was observed and documented. The observation is summarised in the following table. 
International Journal of Innovation, Creativity and Change. www.ijicc.net

Volume 14, Issue 11, 2020

Table 3. Observation result of Children's interest on the use of the Media

\begin{tabular}{llllll}
\hline \multirow{2}{*}{$\mathbf{N o}$} & Indicator & Criteria & & \\
\cline { 2 - 5 } 1 & CL & $\mathbf{L}$ & $\mathbf{M}$ & $\mathbf{H}$ & $\mathbf{V H}$ \\
\hline & $\begin{array}{l}\text { Children's willingness to look at the media by observing } \\
\text { it. }\end{array}$ & & & & \\
\hline 2 & $\begin{array}{l}\text { Children pay attention to the media by asking questions } \\
\text { related to the media. }\end{array}$ & & & \\
\hline & $\begin{array}{l}\text { Children enjoy the use of the media in the learning process } \\
\text { (e.g.: engaging in the classroom activities, paying attention } \\
\text { to the story, etc.) }\end{array}$ & & & \\
\hline
\end{tabular}

Note: VL=Very Low; L=Low; M=Mediocre; H=High; VH=Very High

From Table 3, it can be seen that the children were interested in the media shown. When the media was presented, they engaged in the story by asking questions and identifying the characters in the story. Besides, they also enjoyed the process of using this media by being responsive to the storyteller questions. This observation was also supported by teachers' note which can be seen in the following table.

Table 4. Observation/Interview results on the teachers' opinion towards the use of Media

\begin{tabular}{|c|c|c|c|c|c|c|}
\hline \multirow{2}{*}{ No } & \multirow{2}{*}{ Indicator } & \multicolumn{5}{|c|}{ Criteria } \\
\hline & & VL & $\mathbf{L}$ & $\mathbf{M}$ & $\mathbf{H}$ & VH \\
\hline 1 & $\begin{array}{l}\text { The fascination of the story (theme; characters; } \\
\text { storyline) }\end{array}$ & & & & & $\checkmark$ \\
\hline 2 & The fascination of the pictures & & & & $\sqrt{ }$ & \\
\hline 3 & Efficiency & & & & $\sqrt{ }$ & \\
\hline 4 & Suitability with children's learning interest & & & & & $\sqrt{ }$ \\
\hline 5 & $\begin{array}{l}\text { Suitability with the concept of media in children's } \\
\text { language development (reading readiness) }\end{array}$ & & & & & $\sqrt{ }$ \\
\hline
\end{tabular}

Note: VL=Very Low; L=Low; M=Mediocre; H=High; VH=Very High

Table 4 shows that teachers feel positive about the product. They agree that the theme, characters, and storyline in the book are very interesting and they are highly suitable for children's learning interest. The concept of the product is also suitable for children language development (reading literacy). In terms of pictures and product efficiency, teachers agree that they are interesting and efficient. 
International Journal of Innovation, Creativity and Change. www.ijicc.net

Volume 14, Issue 11, 2020

Based on the finding in the pilot test, the product was then used in the study. This part of the process is useful to investigate the effectiveness of the media in improving children's reading readiness. Children in the experimental group were enthusiastic towards the use of the media. During the process, they engaged in the researcher's storytelling and were even eager to re-tell the story to their friends.

\section{Pre-treatment data}

Before treatment, the sample was tested on their reading readiness. The result of their reading readiness can be seen in the following table.

Table 5. Children's reading readiness before Treatment

\begin{tabular}{cccccc}
\hline No & Indicator & Mean Score & Maximum Score & $\%$ & Criteria \\
\hline 1 & Vocabulary Repertoire & 7.29 & 10 & 72.90 & $\mathrm{M}$ \\
2 & Auditory Discrimination & 6.65 & 10 & 66.50 & $\mathrm{M}$ \\
3 & Visual Discrimination & 6.90 & 10 & 69.00 & $\mathrm{M}$ \\
4 & Reading Test & 38.12 & 54 & 70.59 & $\mathrm{M}$ \\
\hline & Total & $\mathbf{5 8 . 9 6}$ & $\mathbf{8 4}$ & $\mathbf{2 7 8 . 9 9}$ & \\
\hline Means & & & $\mathbf{6 9 . 7 5 \%}$ & $\mathrm{M}$ \\
\hline
\end{tabular}

Based on table 5, it can be seen that the highest score is on the $1^{\text {st }}$ indicator which is related to the children's vocabulary repertoire with a high of $7.29(72.90 \%)$, or mediocre category. Whereas, the lowest score is in the $2^{\text {nd }}$ indicator which reflects the ability to identify and discriminate sounds which they heard. This indicator stands at a low of 6.65 (66.50\%) which falls into a mediocre category. Overall, the mean score of the children's reading readiness before treatment was $69.75 \%$ and classified as mediocre.

\section{Post-treatment}

The test is given twice to the experimental group, while it is given only once to the control group. In terms of scores achieved by the control group, this can be seen in the following table. 
International Journal of Innovation, Creativity and Change. www.ijicc.net

Volume 14, Issue 11, 2020

Table 6. Control Group's Score

\begin{tabular}{clcccc}
\hline No & \multicolumn{1}{c}{ Indicator } & Mean Score & Maximum Score & $\%$ & Criteria \\
\hline 1 & Vocabulary Repertoire & 8.06 & 10 & 80.60 & $\mathrm{H}$ \\
\multirow{2}{*}{2} & $\begin{array}{l}\text { Auditory } \\
\text { Discrimination }\end{array}$ & 6.82 & 10 & 68.20 & $\mathrm{M}$ \\
3 & Visual Discrimination & 7.52 & 10 & 75.20 & $\mathrm{M}$ \\
4 & Reading Test & 34.33 & 54 & 63.57 & $\mathrm{M}$ \\
\hline \multicolumn{1}{c}{ Total } & $\mathbf{5 6 . 7 3}$ & $\mathbf{8 4}$ & $\mathbf{2 8 7 . 5 7}$ & \\
\hline \multicolumn{2}{c}{ Means } & & & $\mathbf{7 1 . 8 9 \%}$ & $\mathrm{M}$ \\
\hline
\end{tabular}

Table 6 shows that the mean score of the control group is $71.89 \%$ and classified as mediocre (M). The highest score is on vocabulary category, which accounted for $80.60 \%$ and can be classified into High category. It is followed by visual discrimination (75.20\%) and auditory discrimination $(68.20 \%)$. However, the reading test is found to be the lowest score of all categories $(63.57 \%)$.

Table 7. The Score of Experimental Group

\begin{tabular}{clcccc}
\hline No & \multicolumn{1}{c}{ Indicator } & Mean Score & $\begin{array}{c}\text { Maximum } \\
\text { Score }\end{array}$ & \% & Criteria \\
\hline 1 & Vocabulary Repertoire & 9.05 & 10 & 90.50 & $\mathrm{H}$ \\
\multirow{2}{*}{2} & Auditory & & & & \\
& Discrimination & 8.71 & 10 & 87.10 & $\mathrm{H}$ \\
3 & Visual Discrimination & 8.75 & 10 & 87.50 & $\mathrm{H}$ \\
4 & Reading Test & 45.59 & 54 & 84.42 & $\mathrm{H}$ \\
\hline \multicolumn{2}{c}{ Total } & $\mathbf{7 2 . 1}$ & $\mathbf{8 4}$ & $\mathbf{3 4 9 . 5 2}$ & \\
\hline \multicolumn{2}{c}{ Means } & & & $\mathbf{8 7 . 3 8 \%}$ & $\mathrm{H}$ \\
\hline
\end{tabular}

Table 7 shows that the mean score of the experimental group is in a High category. As the control group score, the highest mean score in the experimental group is also in vocabulary repertoire. Children show a very high score in this category, which accounted for 9.05 $(90.50 \%)$. It is followed by visual and auditory discrimination with relatively similar means score (8.75 and 8.71 respectively). Even though the reading test is the lowest score in experimental group, the means score is classified as High (84.42\%). 
Before testing the significance of the improvement, the data are tested in terms of their homogeneity, linearity and normality. The statistics results show that the homogeneity test result is 0.111 ( $\mathrm{Sig} .>0.05$ ) and its linearity is 0.004 (Sig. < 0.05). This means that the data are homogenous and linear. Besides, the results of the normality test for control and experimental group are 0.667 and 0.111 respectively (Sig. >0.05) which indicates that they are normally distributed. Therefore, the t-test can be used to find out the difference between the control and experimental groups. The result of the statistics is shown in Table 9.

Table 8. The Result of Independent Samples t-test

Independent Samples Test

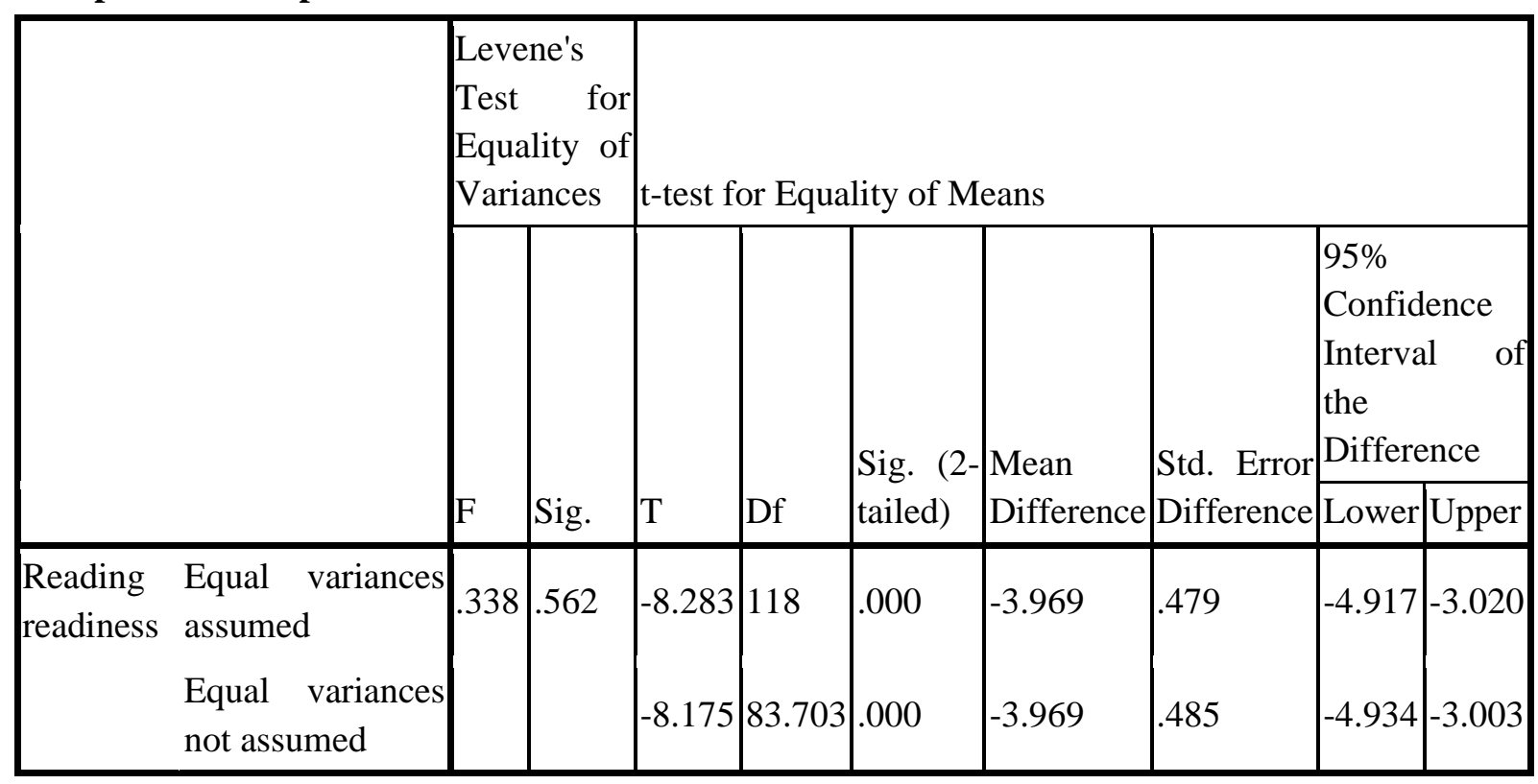

From the Table, it can be seen that the $\mathrm{T}$ score is -8.175 ( $\mathrm{T}>0.05$.). As it is higher than the $\mathrm{T}$ table, it can be concluded that there is a statistically significant difference between the control and experimental group.

\section{DISCUSSION}

To support children's early reading, the media of the Malay folktale picture book is developed through several steps. The first step was to select the theme and the story which was suitable for children. In this case, the story of 'Kancil' (mouse deer) was chosen. As it had many versions, the story of the mouse deer, the tiger and the elephant was considered an enjoyable story for children as they tend to like stories with many animal characters.

After the theme and the story were selected, the media was designed by drawing the early pictures using a pencil. The draft of the story was also written. This early work was considered as an early design of the product so that it was only discussed among the researchers. No 
external review was carried out yet. It was only after the draft was computerised that the work was sent to the reviewer for the validation process.

The first validation result has returned to the researchers with some comments and suggestions. The overall media was accepted, but it needs several improvements in terms of colour. This is in line with Mueller, (2005) who suggests that children tend to like interesting books with colourful pictures. The media was then coloured using a computer before it was printed on A4 paper and sent for second validation. The second reviewer suggested that the media should be made bigger and printed on a glossy paper to highlight the colour. Therefore, the thicker, glossy paper was used to make it easier for classroom use.

As shown in the observation result taken from a limited field test, the children were very interested in the picture book. They showed their interest in the book when it was used by the teacher in the classroom. Based on the observation, children seemed to engage with the classroom activities when the teacher was telling the story by using the book. They actively asked questions to and answered questions from their teacher. This agrees with Walsh (2003) who points out that the children will be more interested in pictures or illustrations of an object which they see in the book.

From the teacher's perspective, the media is considered highly interesting in terms of the theme, the characters and the storyline. Besides, the pictures also support the story well. The suitability of the media is very good and teachers feel that it is efficient to use the media when storytelling in the classroom. A good storytelling method supported with good media would not only support the language development of the children, but also influence children's reading interest which in turn can lead to their improvement in reading skills (Miller \& Pennycuff, 2008; Wayne, DiCarlo, Burts \& Benedict, 2007).

After obtaining a positive result from limited field testing, the main field test was then carried out. It was carried out on the experimental group. During the process, children showed an interest in the media. They were even eager to re-tell the story in front of the classroom with their own words. It shows the role of media to stimulate children's imagination. As imagination is one of the main factors for children's literacy (Egan, 2006; Paley, 2004), it highlights the effectiveness of fable which is told using picture books.

As the media had been developed, the next step was to investigate its effectiveness in improving children's reading readiness. Based on the early observation, it was found that children's reading readiness was $69.75 \%$ which can be classified as mediocre $(\mathrm{M})$. When the study was carried out the reading readiness of control group was $71.89 \%(\mathrm{~N}=43)$, while the experimental group after treatment was $87.38 \%(\mathrm{~N}=77)$. The score achieved by the experimental group after treatment was higher than the control group. It shows that there was an improvement in terms of children reading readiness using the Malay folktale picture book. This finding speaks to 
many other studies which suggest similar results (Eliza, 2018; Montgomery \& Smith, 2014; Van de Heuvel-Panhuizen, Elia \& Robitzsch, 2016).

In addition to the overall data collection, a statistical test was done to find out the level of significance of the improvement. Therefore, the t-test was done using the SPSS software to identify the difference between the control and the experimental group. As the t-test result was -8.175 with significance level $5 \%$, it shows that there was a significant difference between the scores of the two groups. Therefore, it can be concluded that the Malay folktale picture book can improve children reading readiness.

However, it should be noted that reading readiness is different from reading ability, in a way that readiness deals with children attitude and behaviour which shows their motivation to identify their surroundings including other media, such as pictures, letters or texts (Smith \& Chapel, 1970). The media used the story with the mouse deer (Kancil) as the main character because this character is well known which is expected to motivate the children to improve their reading readiness. This is also supported by the visual which has been designed based on children interest. This supports Bruner's (1966) view claiming that language development in children has three stages, namely enactive (movement), iconic (images) and symbolic (symbols). Due to the familiarity with the story, during the research process children were able to actively involve in the storytelling; they observed, listened to and asked about the story. In this process, they started to develop their language skills through multisensory activities. Besides, the fact that there was an improvement regarding their reading readiness also showed a positive sign that they were reaching the last stage of language development. Therefore, the media developed in this study is suggested to be able to stimulate children's development in these three stages.

\section{CONCLUSION}

This study is an R\&D research which aimed to develop a learning media for children's reading readiness. The use of a Malay folktale as the story is because it was found that the children had a relatively low level of reading readiness. Besides, it is also acknowledged that the Malay folktale has potential as it has been a popular story across the country. Based on the findings, it can be concluded that the use of the Malay folktale picture book developed in this study can improve children's reading readiness. However, it cannot be generalised due to a limited number of sample and their backgrounds in terms of culture and access to technology. Even though it used specifically for the local culture from Malay, it is expected to shed a light on the importance of local culture in children language development. The findings of this study also generate some suggestions as follows:

1. The familiarity of a story might be one of the key factors in supporting children's early reading, so educators and parents are expected to select reading and teaching materials for improving children's readiness which is authentic and from their local culture. 
International Journal of Innovation, Creativity and Change. www.ijicc.net

Volume 14, Issue 11, 2020

2. The government could develop some fables which are based on local culture and animal characters with which children like to improve their reading interest. This is expected to affect their reading readiness positively.

3. The researchers are also expected to develop media which focus on different aspects of children development, such as emotional, moral, cognitive and religious aspects.

4. As this study is still limited in terms of the number of participants, the finding is not generalisable. Therefore, further research in other contexts and with a larger number of participants is needed. 
International Journal of Innovation, Creativity and Change. www.ijicc.net

Volume 14, Issue 11, 2020

\section{REFERENCES}

Battle, D. E. (2009). Multiculturalism, language, and emergent literacy. In P. M. Rhyner, Emergent literacy and language development: Promoting learning in early childhood (pp. 192-234). New York: The Guilford Press.

Bauer, E., \& Guerero, B. (2016). Young children's emerging identities as bilingual and biliterate students. In A. Anderson, J. Anderson, Hare, \& M. McTavish, Language, learning and culture in early childhood: Home, school and community contexts (pp. 19-49). New York: Routledge.

Bay, D. N., \& Cetin, O. S. (2014). Storybook reading strategies of preschool teachers in the USA and Turkey. International Journal of Education and Research, 2(7), 41-54.

BPS-Statistics Indonesia. (2019, August 12). Indikator pendidikan, 1994-2018 [Education indicator, 1994-2018]. Retrieved December 11, 2019, from Badan Pusat Statistik: https://www.bps.go.id/statictable/2010/03/19/1525/indikator-pendidikan-19942018.html

Brooks, W. (2006). Reading representations of themselves: Urban youth use culture andafrican american textual features to develop literary understandings. ReadingResearch Quarterly, 41(3), 372-392. http://dx.doi.org/10.1598/RRQ.41.3.4

Bruner, J. S. (1966). Toward a theory of instruction. Cambridge: Belkapp Press.

Cetin, O. S., \& Bay, N. (2015). Enhancing the early reading skills: Examining the print features of preschool children's book. International Education Studies, 8, 113-124.

Dickinson, D. K., McCabe, A., Anastasopoulos, L., Peisner-Feinber, E. S., \& Poe, M. D. (2003). The comprehensive language approach to early literacy: The interrelationships among vocabulary, phonological sensitivity, and print knowledge among preschool-aged children. Journal of Educational Psychology, 95(3), 465-481.

Egan, K. (2006). Teaching literacy: Engaging the imagination of new readers and writers. Newbury Park: Corwin Press.

Eliza, D. (2018). Emergent literacy based on wordless picture book to introduce Minangkabau cultural value and identity for early childhood. dvances in Social Science, Education and Humanities Research (ASSEHR), 169, 284-288.

Garth-McCullough, R. (2008). Untapped cultural support: The influence of culturally bound prior knowledge on comprehension performance. Reading Horizons, 49(1), 1-30.

Hall, K.W. (2008). Reflecting on our read-aloud practices: The importance of includingculturally authentic literature. Young Children, 63(1), 80-86. 
International Journal of Innovation, Creativity and Change. www.ijicc.net Volume 14, Issue 11, 2020

Hefflin, B. R., \& Barksdale-Ladd, M. A. (2001). African american children's literaturethat helps students find themselves: Selection guidelines for grade k-3. The Reading Teacher, 54(8), 810-819.

Hester, E., \& Hodson, B. (2009). Methaphonological awareness: Enhancing literacy skills. In P. M. Rhyner, Emergent literacy and language development: Promoting learning in early childhood (pp. 78-103). New York: The Guilford Press.

Hoff, E. (2005). Language development (3rd ed.). United States of America: Thomson Wadsworth.

Jalongo, M. R. (2007). Early childhood language arts (4th Edition ed.). Boston, MA: Pearson Education, Inc.

Jiar, Y. K.,\&Johan, O. M.(2008). Reading Readiness Test for Kindergarten Children. Jurnal Teknologi, 49(E), 129-139. doi:10.11113/jt.v49.214

Justice, L. M., Kaderavek, J. N., Fan, X., Sofka, A., \& Hunt, A. (2009). Accelerating preschoolers' early literacy development through classroom-based teacher-child storybook readin and explicit print referencing. Language, Speech, and Hearing Services in Schools, 40, 67-85.

Kenner, C. (2004). Becoming bilingual: Young children learning different writing systems. Stoke on Trent: Trentham Books.

Kirk, C., \& Gillon, G. (2007). Longitudinal effects of phonological awareneess intervention on morphological awareness in children with speech impairment. Language, Speech, and Hearing Services in Schools, 38, 342-352.

Lawrence, S. A., Johnson, T., Baptiste, M., Caleb, A., Sieunarine, C., \& Similien, C. (2017). Pre-service teachers' use of multicultural literature. Journal of Inquiry \& Action in Education, 9(1), 28-47.

Lohfink, G. (2010). The nature of Mexican American third graders' engagement with culturally relevant picture books. Bilingual Research Journal, 33(3), 346363.doi:10.1080/15235882.2010.529346

Lyle, S., \& Bolt, A. (2017). What brings children to writing and energises their early writing efforts? In C. J. McLachlan, \& A. W. Arrow, Literacy in the early years: Reflections on international research and practice (pp. 93-110). Singapore: Springer.

Manolitsis, G., \& Kandylidou, E. (2011, August). Morphological awareness instruction in kindergarten and children's early literacy development. Paper presented at the 17th European conference on reading. Mons, Belgium. 
International Journal of Innovation, Creativity and Change. www.ijicc.net Volume 14, Issue 11, 2020

Miller, S., \& Pennycuff, L. (2008). The power of story: Using storytelling to improve literacy learning. Journal of Cross-Disciplinary Perspectives in Education, 1(1), 36-43.

Montgomery, A. P., \& Smith, K. M. (2014). Together in song: Building literacy relationships with song-based picture books. Language and Literacy, 16(3), 27-53.

Moore, L. C. (2017). Multilingual socialization and education in non-Western setting. In P. A. Duff, \& S. May, Language socialization (3rd ed., pp. 155-168). Switzerland: Springer.

Mueller, S. (2005). Everyday literacy: Environmental print activities for children 3 to 8. United States of America: Gryphon House, Inc.

Norton, D., \& Norton, S. (2010). Through the eyes of a child: An introduction to children's literature $\left(8^{\text {th }}\right.$ ed.). Boston, MA: Prentice-Hall.

Nurhayati, W. (2018). The development of school readiness instrument and mapping school readiness. Indonesian Journal of Educational Assessment, 1(1), 11-22.

Owen Jr, R. E. (2012). Language development: An introduction (8th ed.). New Jersey: Pearson Education, Inc.

Paley, V. G. (2004). A child's world: The importance of fantasy play. Chicago: The University of Chicago Press.

Paran, A., \& Wallace, C. (2016). Teaching literacy. (G. Hall, Ed.) London: Taylor and Francis.

Parlakian, R., \& Sanchez, S. A. (2006). Cultural influences on early language and literacy teaching practices. Zero to Three, 52-57.Perry, K. (2012). What is literacy? A criticaal overview of socioultural perspectives. Journal of Language and Literacy Education, 8(1), 50-71.

Rhyner, P. M., Haebig, E. K., \& West, K. M. (2009). Understanding frameworks for the emergent literacy stage. In P. M. Rhyner, Emergent literacy and language development (pp. 3-35). New York: The Guilford Press.

Roche, M. (2015). Developing children's critical thinking through picturebooks. New York: Routledge.

Rogoff, B. (2003). The cultural nature of human development. Oxford: Oxford Unniversity Press.

Saccardi, M. (2014). Creativity and children's literature: New ways to encourage divergent thinking. Santa Barbara, California: Libraries Unlimited.

Smith, D. E., \& Chapel, J. R. (1970). Reading Readiness. Reading Horizons: A Journal of Literacy and Language Arts, 10(2), 58-62. 
International Journal of Innovation, Creativity and Change. www.ijicc.net

Volume 14, Issue 11, 2020

Storch, A. S., \& Whitehursst, G. J. (2002). Oral language and code-related precursors to reading: Evidence from a longitudinal structural model. Developmental Psychology, 38(6), 934-947.

Tarim, S. D. (2015). Literacy development of preschool education classrooms in Turkey: The case of Mugla. Journal of Education and Training Studies, 3(5), 264-270.

Teale, W. H., \& Sulzby, E. (1986). Emergent literacy as a perspective for examining how young children become writers and readers. In W. H. Teale, \& E. Sulzby, Emergent literacy: Writing and reading (pp. vii-xxv). Norwood, NJ: Ablex.

Van de Heuvel-Panhuizen, M., Elia, I., \& Robitzsch, A. (2016). Effects of reading picture books on kindergartens' mathematical performance. Educational Psychology, 36(2), 323-346.

Wallace, C. (2013). Literacy and the bilingual learner: Texts and practices in London School. London: Palgrave Macmillan.

Walsh, M. (2003). 'Reading' pictures: what do they reveal? Young children's reading of visual texts. Literacy, 37(3), 123-130.

Wayne, A., DiCarlo, C. F., Burts, D. C., \& Benedict, J. (2007). Increasing the literacy behaviors of preschool children through environmental modification and teacher mediation. Journal of Research in Childhood Education, 22(1), 5-17.

Wiseman, A. (2011). Interactive read alouds: Teachers and students constructing knowledge and literacy together. Early Childhood Education Journal, 38(6), 431-438.

Wood, S., \& Jocius, R. (2013). Combating "I hate this stupid book!": Black males and critical literacy. Reading Teacher, 66(8), 661-669. http://dx.doi.org/10.1002/TRTR.1177 